\title{
The florist
}

$\mathrm{O}$ range daylight lit the sliding glass panes of the hospital exit. I emerged into a cold Saturday in November, the morning after the season's first snowfall. It had been a particularly rough night, and I was grateful for the crisp air on my walk home.

Along my route, there was a small flower shop whose windows billowed with exotic flora. I tried the door on a whim, and was surprised to find it open even at this early hour. A bell jingled as I stepped inside and kicked packed snow from my boots.

The man behind the counter was sixtyish, with thinning white hair and an olive complexion. He sat bent over an array of magnificent flowers in shades of blue, purple and lavender. $\mathrm{He}$ seemed engrossed in his work, and I waited, hesitant to disturb him.

"Delphinium," he said, without looking up.

"Excuse me?"

Suddenly he rose from his stool. His smile was warm. "Delphinium. Just arrived yesterday. Your wife, she will love them."

It took a moment before I realized that I had removed my gloves, exposing raw pink fingers and a silver wedding band. "That would be perfect. Thank you."

We spoke little while he prepared the arrangement, cajoling a beauty recognize. My eyes felt heavy, and I closed them momentarily.

After some time I became aware that the humming had stopped. I opened my eyes to find the white-haired man observing me with a curious expression on his face. What he said next instantly released me from my torpor.

"You are a doctor, yes?"

I was stunned. I searched my body for telltale signs of my vocation: a stethoscope draped around my neck, a hospital ID tag hanging from my shirt pocket. But I had changed my clothes before leaving the hospital and had stowed the tools of my trade in my footlocker.

"Yes. Yes, I am."

He smiled and nodded as if I had just confirmed that the sky was blue or the earth was round. He turned back to his work, humming again beneath his breath.

I felt stirred. It was a question I had never been asked before. My father, a family physician, had occasionally been told that he looked like a doctor, but he had white hair and was always meticulously shaven. I was thirty and unkempt after a long night's work. As far as I could tell, nothing about my physical attributes suggested a particular professional affiliation. At present, there was nothing medical about me.

What was it that made my occupa-

\section{As far as I could tell, nothing about} my physical attributes suggested that I was a doctor.

from the whole that transcended that of its parts. I watched as he handled the o flowers expertly with the same delicate respect that I reserve for the examination of my patients. His movements were mesmerizing. The quiet warmth of the shop was soothing. The man hummed while he worked - soft, breezy strains of something I didn't tion so transparent now, to this man who had never met me before? Did the grip of my hand disclose the nature of its expertise? Was there a gentleness in my voice that bespoke compassion? Was benevolence inherent in my demeanor?

The older man had wandered off to gather a few ornamental blossoms to complete the bouquet. I called to him

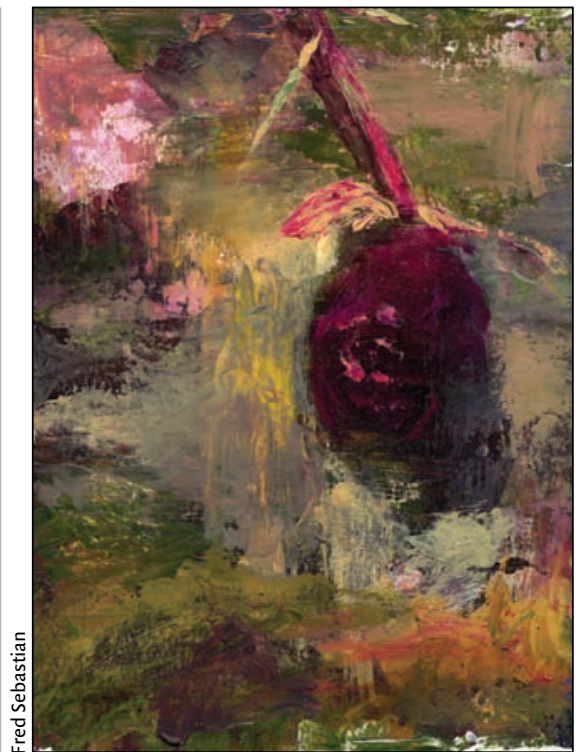

across the room.

"How did you know?"

"I'm sorry, sir?" The feat that had so astounded me had slipped from his mind like yesterday's grocery list.

"That I'm a doctor. How did you know that?"

For a long moment he remained silent, scrutinizing me as he had done earlier. Puffs of baby's-breath sprouted from his hands.

"Do you know what is qanat?" he said at length.

"No."

The man approached, setting the flowers down carefully on the counter. He explained that qanat was a Semitic word meaning "to dig," and referred to the elaborate irrigation systems that were invented in Persia thousands of years ago. These underground conduits, he said, were created to bring mountain water to the desert plains. People obtained water by moving stone slabs that covered these hidden channels. In some areas, the water reached the surface, flowing through stone gutters along the streets and alleys.

"When I was a boy in Iran," he said, "my friends and I played football in the streets of our village. When we could play no longer, we sat and cooled our feet in the qanat waters. It was the time 
of day when the men hurried to the mosques, and the women returned from the markets, and the children ran home to complete their schoolwork.

"We watched these strangers as they passed us by. 'That one,' we would say, 'he has sold many items today. His business has done well.' Or: 'That one,' we would say, 'she is angry with her husband. She will not cook well tonight.' It was a game that we enjoyed very much. And I ... I was very clever at this game. Once, I remarked about a young man: 'That one, he has the voice of a songbird and the devotion of a mare.' My friends were intrigued, so they followed this man through winding streets of the village. They found him at the top of a minaret: he was a muezzin, the one who calls the faithful to prayer!"

He paused, turning his gaze on me.

"I have been in this country since I978. Many strangers have passed in and out of my small shop. When you entered, I said to myself, 'That one: $\mathrm{He}$ is a doctor."'

The man's story was captivating. While he spoke, I found myself considering not what he had come to know about me, but rather what I understood about him. This was a man who had once known turbulence, tragedy and exile. Now, a certain serenity envelopped him, as if, among flowers, he felt vindicated for a lifetime of hardship. I sensed I knew these things with the same clarity he must have felt as a boy with his aching feet immersed in water.

We shook hands after he handed me the finished bouquet wrapped in a protective covering.

"You would make an excellent doctor," I said.

He smiled, his eyes sparkling. "And you, an excellent florist."

I left the shop, holding the flowers close to my chest. Outside, the sun was high and the streets were alive with morning bustle as people made their way to work for the day.

\section{Stuart Lubarsky}

$\mathrm{PGY}_{3}$, Neurology

McGill University

Montréal, PQ

\section{Notes \\ Raising Lazarus}

Grand rounds in medicine are, well, grand affairs. In my student days the senior don, a super-cat physician, would lead us, a motley flock of interns, final-year medicos and postgraduate students as he tapped a chest here and palpated a liver there. He was a genius, this man, and he knew it. He could verily see through the patient. We were in awe of him.

One morning, as we scurried behind him through the wards, we heard an unearthly groan rising from a corridor-side bed: laryngeal stridor producing a nerve-freezing wheeze and splutter. But this was more. The last throes of death. A desperate attempt to ward off the designs of Atropos. We novice interns, as yet unschooled in the proximity of death, went jittery. The professor moved on. It wasn't his patient. But one of my fellow novitiates, a fresh house-surgeon, stood transfixed. Just beyond, a man lay flailing, fending off with weakened fists and weakening resolve the machinations of Yama.

"Can we do something, Sir?" my classmate gingerly queried the professor, who turned round to wonder why this joker, this dodo in a white coat, wasn't moving with the herd.

"Do what, Doc? Just a few pages of Davidson \& Price and already a cardiologist, eh? Do something, indeed," the don snorted.

The rest of us shivered in our pants. The man's temper was as famous as his wizardry in his subject. But the stubbornly stupid Subbu was unfazed. He blurted, "Something, Sir, anything! Intracardiac adrenaline?"

"Oho, adrenaline indeed! I wonder how could I have forgotten that, Doctor? Now, shall we try and resurrect this Lazarus!"

We all stood motionless. This dodo, why couldn't he keep his mouth shut like the rest of us? We were all going to get it now, in style, and in ample measure, too. As we braced ourselves for Vesuvius to erupt, the senior don snatched a stethoscope from the nearest student and purposefully entered the ward, striding up to the dying (and, mercifully, now dead) patient. With a derisive earnestness he dabbed the bell of the stethoscope this way and that, unplugged the earpieces, and handed them to the insolent dodo, his right hand firmly affixed on bell, which he held exactly over the heart-sounds zone. The message was: Now take over, the patient is yours.

The imbecile, Subbu, was as dumb as they come. Instead of blurting out an apology and calling curtains, he, the numbskull, plugged the stethoscope into his ears and auscultated the dead man's chest. The don's fuse was sputtering with electricity and smoke. He had to explode soon.

Then, to our amazement, Subbu trotted to the medicine counter, filled up a syringe with adrenaline, ran back and drove the needle home, straight into the chest between and through the left parasternal intercostal space.

He had hardly finished when we heard in the deafening silence that now enveloped the ward a low growl and groan rising from the throat of the dead man. Lo, his chest began to heave. The dead man had returned to life.

Suavely, Subbu dabbed the stethoscope over the thoracic wall, this way and that, and in a final show of utter contempt pulled out the earpieces and handed them over to the grandmaster of cardiology, keeping his right palm firmly affixed on the bell, which he held over the heart sounds.

What the don heard through the stethoscope, I don't know. But I suspect it was a voice that drubbed, over and over, "Physician, heal thyself."
Arunachalam Kumar
Vice Dean (Academic)
K.S. Hegde Medical Academy
Mangalore, India 